\title{
Staphylococcus aureus AMPICILLIN-RESISTANT FROM THE ODONTOLOGICAL CLINIC ENVIRONMENT
}

Wagner Luis de Carvalho BERNARDO, Marcelo Fabiano Gomes BORIOLLO, Reginaldo Bruno GONÇALVES \& José Francisco HÖFLING

\begin{abstract}
SUMMARY
The aim of this research was to evaluate the prevalence of Sthaphylococcus spp. and S. aureus in the odontological clinic environment (air), their production of $\beta$-lactamase and antibacterial susceptibility to the major antibiotics utilized in medical particle. During 12 months of samples collect were isolated 9775 CFU by MSA medium suggesting a high amount of Staphylococcus spp. in the clinic environment which can appear through aerosols. A total of 3149 colonies (32.2\%) were suggestive of pathogenic staphylococci. Gram coloration, catalase test, colony-mallow growing on chromogenic medium, and coagulase test confirmed the identity of $44(0.45 \%)$ S. aureus isolates. Of these, 35 isolates $(79.5 \%)$ showed production of $\beta$-lactamase by Cefinase ${ }^{\mathrm{TM}}$ discs and resistance to ampicillin, erythromycin (7 isolates) and tetracycline (1 isolate) suggesting the existence of multiresistant isolates. The evaluation of the oxacillin MIC by Etest ${ }^{\circledR}$ assays showed susceptibility patterns suggesting the inexistence of the mecA gene in chromosomal DNA. These results point out to the need of a larger knowledge on the contamination means and propagation of this microorganism into the odontological clinic.
\end{abstract}

KEYWORDS: Staphylococcus aureus; Ampicillin-resistant; Odontological clinic environment.

\section{INTRODUCTION}

The Staphylococcus aureus is an opportunist pathogen found in the microbiota of mucous membrane (buccal, nasal, aural) and skin human, capable to cause serious infections when penetrating in the human organism ${ }^{25,33}$. Among the infectious diseases caused by those bacteria are the septicaemia, pneumonia, endocarditis, osteomyelitis, gastroenteritis and abscess ${ }^{4}$. In the last years, a strong correlation between isolation of $S$. aureus and occurrence of nosocomial infections became a constant problem to hospitals and clinical centers. In addition, the isolation and the prevalence of multi-resistant strains to antibiotics have been demonstrated in several nosocomial and clinical environments ${ }^{4,12,29}$. The odontological clinic was also considered an environment of infectious agent cross-transmission. Researches have been showing the transmissibility of $S$. aureus strains during dental treatments, including meticillin-resistant strains (MRSA - Methicillin-resistant Staphylococcus aureus) that occasionally can lead to contamination and infection of patients ${ }^{26}$. However, the progression of the colonization to infection was referred as a dependent process of the host defense mechanism and of the ability of these bacteria to overcome such mechanism. Once established an infectious process becomes essentially important the use of appropriate methods to identification of microbial strains, as well as their association to the antibacterial sensibility tests (resistotyping) in order to favor the selection of efficient drugs to the combat of such process $^{22}$. Taking into consideration the great potential pathogenic of multi-resistant $S$. aureus strains and the high risks of transmissibility of that species in odontological clinic environmental, the objective of this research was to evaluate the (i) prevalence of Staphylococcus spp. and $S$. aureus in the odontological clinic environmental (air) for 12 months, (ii) production of $\beta$-lactamase for $S$. aureus isolates, and (iii) antibacterial susceptibility of this specie to the majors antibiotics utilized in medical particle, especially oxacillin.

\section{MATERIAL AND METHODS}

Isolation and identification: Staphylococcus species were isolated from clinical environment (air) of the Dental School of Piracicaba, State University of Campinas (FOP/UNICAMP - Faculdade de Odontologia de Piracicaba, Universidade Estadual de Campinas), Piracicaba, State of São Paulo, Brazil. The isolation of those bacteria happened directly by open plates containing MSA selective medium (Mannitol Salt Phenol-red Agar, Merck, Darmstadt, Germany) disposed in 12 odontological clinic environments for two hours, during intense and periodical multi-activities (dentistical, periodonty, endodonty, orthodontia and/or surgery) of the integrated clinic and urgency duty. Such proceeding was accomplished for 12 months, twice to month with intervals of \pm 15 days between one collect and other one totaling 24 collects (from September to December middle, 2000; from March to June, 2001; from August to December middle, 2001). Afterwards, the plates were led to incubation at $37^{\circ} \mathrm{C}$ for 48 hours. After the growing 
of the cultures, the indicative colonies of mannitol fermentation by pathogenic staphylococci (presence of yellow halo around of the colonies) were selected ${ }^{10}$. The characterization of Staphylococcus spp. and $S$. aureus was done by stain of Gram, growth in chromogenic medium CHROMagar Staphylococcus aureus ${ }^{\circledR}$, catalase test and coagulase test - gold standard - (Coagu-Plasma, Laborclin Produtos para Laboratórios Ltda.). Mallow color, catalase-positive and coagulasepositive colonies were identified as $S$. aureus $^{11,15,18,19}$.

$\beta$-lactamase test: $S$. aureus colonies grown in NA medium (Nutrient Agar, Merck, Darmstadt, Germany) were transferred to surface of microscopy lamina containing Cefinase ${ }^{\mathrm{TM}}$ discs (Becton Dickinson \& Company, USA) soaked with sterile water distilled. The Cefinase $^{\mathrm{TM}}$ discs contain chromogenic cephalosporin (nitrocefin) of yellow color. In the $\beta$-lactamase presence, the ring $\beta$-lactamic undergo hydrolise originating red color discs. Thus, the interpretation of the results was made according to the manufacturer's instructions.

Resistotyping: The evaluation of resistance to the antibiotics was accomplished by discs diffusion $\operatorname{method}^{2}$. S. aureus cultures were growing in BHI broth (Brain Heart Broth, Merck, Darmstadt, Germany) at $37^{\circ} \mathrm{C}$ for two to eight hours and it was standardized to a concentration of 0.5 in the MacFarland scale $\left(1.5 \times 10^{8}\right.$ CFU.ml $\left.{ }^{-1}\right)$. Such cultures standardized were inoculated in plates containing MHA medium (Mueller Hinton Agar, Difco Ltd.). Afterwards, discs containing ampicillin, amoxicillin, cephalothin, clindamycin, erythromycin, oxacillin, tetracycline and vancomycin (Cecon Ltd.) were put into plates and then led to incubation at $37^{\circ} \mathrm{C}$ for 24 to 48 hours. The interpretation of the inhibition halo patterns was done according to the norms established by NCCLS ${ }^{18,21}$.

Oxacillin MIC (Minimum Inhibitory Concentration): S. aureus cultures grown in $5 \mathrm{~mL}$ of BHI broth (Brain Heart Broth, Merck, Darmstadt, Germany) at $37{ }^{\circ} \mathrm{C}$ for two to eight hours were standardized to a concentration of 0.5 in the MacFarland scale $\left(1.5 \times 10^{8} \mathrm{CFU} \cdot \mathrm{mL}^{-1}\right)$ and inoculated in MHA medium (Mueller Hinton Agar, Difco Ltd.) supplemented with $\mathrm{NaCl} 0.4 \%$ w/v. Therefore, Etest ribbons (Etest ${ }^{\circledR}$ AB Biodisk, Sweden) containing oxacillin (concentration gradient from 0.0163 to $256 \mu \mathrm{g} \cdot \mathrm{mL}^{-1}$ ) were put on MHA medium and posteriorly it was led to incubation at $37{ }^{\circ} \mathrm{C}$ for 24 hours ${ }^{6,9}$. The interpretation of the inhibition halo patterns was also done according to the norms established by NCCLS ${ }^{21}$.

\section{RESULTS}

According to database of the Odontology Service from the Dental School of Piracicaba were attended, on average, 128 patients per day during the isolation of the samples. A total of 9775 colonies (average of 407 per collect) were isolated from odontological clinic environment during the isolation period by SMA plates. However, 3149 colonies $(32.2 \%)$ were indicatives of pathogenic Staphylococci (mannitol fermentation), and only 44 colonies $(0.45 \%)$ were identified as $S$. aureus by stain of Gram, growth in chromogenic medium CHROMagar Staphylococcus aureus ${ }^{\circledast}$, catalase test and coagulase test (Fig. 1). In addition, the isolation of $S$. aureus not showed specificity to any area of the odontological clinic, although have occurred a variable prevalence of this specie in certain areas, but timidly higher prevalence to the areas $\mathrm{C}$ and $\mathrm{G}$ (Fig. 2).

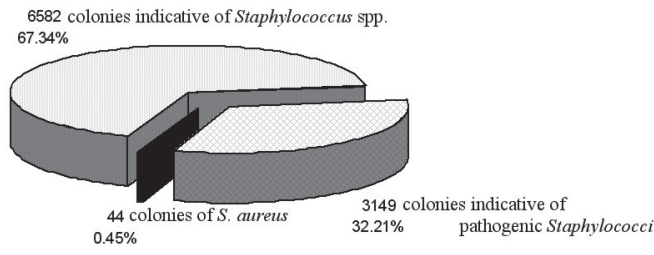

Fig. 1 - Prevalence of Staphylococcus species and S. aureus in the odontological clinic environments (air).

\begin{tabular}{|rcccccccccccc|}
\hline \multirow{2}{*}{ Date } & \multicolumn{1}{c}{ Areas of the odontological clinic } & & \\
\cline { 2 - 11 } & A & B & C & D & E & F & G & H & I & J & K & L \\
\hline 19/09/00 & 1 & - & - & 1 & 1 & 1 & - & - & - & - & - & - \\
$31 / 10 / 00$ & - & - & - & - & - & - & - & - & - & - & - & - \\
$21 / 10 / 00$ & - & 1 & - & 1 & - & - & - & - & - & - & - & - \\
$28 / 11 / 00$ & - & 1 & - & - & - & 1 & - & - & - & - & - & - \\
$05 / 11 / 00$ & - & - & - & - & - & - & - & - & - & - & - & - \\
$12 / 12 / 00$ & - & - & - & - & 1 & - & - & - & 1 & - & 1 & 1 \\
$06 / 03 / 01$ & - & - & 1 & - & - & - & - & - & - & - & - & - \\
$27 / 03 / 01$ & 1 & - & - & - & - & - & - & - & - & - & - & - \\
$03 / 04 / 01$ & - & 1 & 2 & - & - & - & 1 & - & - & - & 1 & - \\
$17 / 04 / 01$ & - & - & - & - & - & - & - & - & - & - & - & - \\
$15 / 05 / 01$ & 1 & - & - & - & 1 & - & - & - & - & - & 1 & - \\
$29 / 05 / 01$ & 1 & - & - & - & - & - & - & - & 1 & - & - & - \\
$19 / 06 / 01$ & - & - & - & - & - & - & 1 & - & - & - & 1 & - \\
$26 / 06 / 01$ & - & - & - & - & - & - & 1 & - & - & 1 & - & 1 \\
$07 / 08 / 01$ & - & - & 1 & - & - & - & - & - & - & - & 1 & - \\
$28 / 08 / 01$ & - & - & - & - & - & - & - & - & - & - & - & - \\
$11 / 09 / 01$ & - & - & - & - & - & - & - & - & - & - & - & - \\
$25 / 09 / 01$ & - & - & - & - & - & - & - & - & - & - & - & - \\
$09 / 10 / 01$ & - & - & 1 & 1 & - & - & 1 & - & 2 & - & - & - \\
$16 / 10 / 01$ & - & - & 1 & - & - & - & - & - & - & - & - & - \\
$06 / 11 / 01$ & - & - & - & - & - & - & 2 & 1 & - & - & - & - \\
$27 / 11 / 01$ & - & - & - & - & 1 & - & - & - & - & - & - & - \\
$04 / 12 / 01$ & - & - & - & - & - & - & - & - & - & - & - & - \\
\hline Total & 5 & 3 & 7 & 3 & 4 & 3 & 6 & 1 & 4 & 1 & 5 & 2 \\
$\%$ & 11.4 & 6.8 & 15.9 & 6.8 & 9.1 & 6.8 & 13.6 & 2.3 & 9.1 & 2.3 & 11.4 & 4.5 \\
\hline & & & & & & & & & & & & - \\
\hline
\end{tabular}

Fig. 2 - Variable prevalence of S. aureus in several areas of the odontological clinic (from A to $\mathrm{L})$.

A total of 35 S. aureus isolates (79.5\%) showed production of $\beta$ lactamase by Cefinase ${ }^{\mathrm{TM}}$ discs assays and resistance to ampicillin (in accordance to the established by manufacturer), erythromycin (seven isolates $-15.9 \%$ ) and tetracycline (one isolate - 2.3\%). Nine S. aureus isolates $(20.5 \%)$ were $\beta$-lactamase negative and $(i)$ susceptible to all antibacterial (six isolates $-13.7 \%$ ) or (ii) only resistant to erythromycin (three isolates - 6.8\%) (Fig. 3). In addition, all the isolates showed antibacterial susceptibility to amoxicillin (only two isolates showed intermediary levels), cephalothin, clindamycin, oxacillin and vancomycin (Table 1). The evaluation of the minimum inhibitory concentration (MIC) of oxacillin by Etest ${ }^{\circledR}$ assays showed susceptibility 


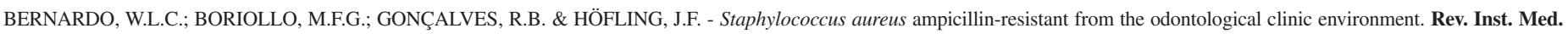
trop. S. Paulo, 47(1):19-24, 2005.

Table 1

Antibacterial susceptibility patterns of 44 S. aureus samples isolated from the odontological clinic environment

\begin{tabular}{|c|c|c|c|c|c|c|c|c|c|}
\hline \multicolumn{2}{|c|}{ S. aureus } & \multirow[t]{2}{*}{ Ampicillin } & \multirow[t]{2}{*}{ Amoxicillin } & \multirow[t]{2}{*}{ Erythromycin } & \multirow[t]{2}{*}{ Clindamycin } & \multirow[t]{2}{*}{ Oxacillin } & \multirow[t]{2}{*}{ Tetracycline } & \multirow[t]{2}{*}{ Cephalothin } & \multirow[t]{2}{*}{ Vancomycir } \\
\hline$n$ & Code* & & & & & & & & \\
\hline 1 & A - 1909 & $\mathbf{R}$ & $S$ & $S$ & $S$ & $\mathrm{~S}$ & $S$ & $\mathrm{~S}$ & $S$ \\
\hline 2 & A - 06031 & $\mathbf{R}$ & S & $\mathbf{R}$ & S & S & S & S & S \\
\hline 3 & A - 27031 & S & S & S & S & S & S & S & S \\
\hline 4 & A - 15051 & $\mathbf{R}$ & S & S & S & S & S & S & S \\
\hline 5 & A - 29051 & S & S & S & S & S & S & S & S \\
\hline 6 & B - 3110 & $\mathbf{R}$ & $S$ & $\mathbf{R}$ & $S$ & $S$ & $S$ & $S$ & $S$ \\
\hline 7 & B - 2111 & $\mathbf{R}$ & I & S & S & S & S & S & S \\
\hline 8 & B - 03041 & $\mathbf{R}$ & S & S & S & S & S & S & S \\
\hline 9 & C - 1212 & S & S & S & S & S & $S$ & S & S \\
\hline 10 & C - 27031 & $\mathbf{R}$ & S & S & S & S & S & S & S \\
\hline 11 & C - 03041 & S & S & $\mathbf{R}$ & S & S & S & S & S \\
\hline 12 & C - 0304I1 & $\mathbf{R}$ & S & S & S & S & I & S & S \\
\hline 13 & C - 07081 & $\mathbf{R}$ & S & S & S & $S$ & I & S & S \\
\hline 14 & C - 09101 & $\mathbf{R}$ & S & $\mathbf{R}$ & S & S & S & S & S \\
\hline 15 & C - 19101 & $\mathbf{R}$ & S & S & S & S & I & S & $S$ \\
\hline 16 & D - 1909 & $\mathbf{R}$ & S & S & S & S & S & S & S \\
\hline 17 & D - 3110 & $\mathbf{R}$ & S & $\mathbf{R}$ & S & S & S & S & S \\
\hline 18 & D - 09101 & $\mathbf{R}$ & I & S & S & S & I & S & S \\
\hline 19 & E - 1909 & $\mathrm{~S}$ & S & $\mathbf{R}$ & S & S & $\mathrm{S}$ & S & S \\
\hline 20 & E - 0512 & $\mathbf{R}$ & S & S & $S$ & S & S & S & S \\
\hline 21 & E - 15051 & $\mathbf{R}$ & $S$ & $S$ & $S$ & S & S & S & $S$ \\
\hline 22 & E - 27111 & $\mathbf{R}$ & S & S & S & $\mathrm{S}$ & I & S & S \\
\hline 23 & F - 1909 & $\mathbf{R}$ & S & S & S & S & S & S & S \\
\hline 24 & F - 2111 & $\mathbf{R}$ & $S$ & $S$ & $S$ & $S$ & $S$ & S & S \\
\hline 25 & F - 27031 & $\mathbf{R}$ & S & $\mathbf{R}$ & S & S & S & S & S \\
\hline 26 & G - 19061 & $\mathbf{R}$ & S & S & S & S & S & S & S \\
\hline 27 & G - 26061 & $\mathbf{R}$ & $S$ & $S$ & $S$ & S & $S$ & S & $S$ \\
\hline 28 & G - 03041 & $\mathbf{R}$ & S & $\mathbf{R}$ & S & S & $S$ & S & S \\
\hline 29 & G - 09101 & $\mathbf{R}$ & S & $S$ & S & S & I & S & S \\
\hline 30 & G - 06111 & $\mathbf{R}$ & S & $\mathbf{R}$ & $S$ & $S$ & $S$ & S & S \\
\hline 31 & $\mathrm{G}-06111 \mathrm{I}$ & $\mathbf{R}$ & S & S & S & S & S & S & S \\
\hline 32 & $\mathrm{H}-06111$ & $\mathbf{R}$ & S & S & S & S & I & S & S \\
\hline 33 & I - 0512 & $\mathbf{R}$ & S & S & $S$ & $S$ & $S$ & S & $S$ \\
\hline 34 & I - 29051 & $\mathbf{R}$ & S & S & S & S & $S$ & S & S \\
\hline 35 & I - 09101 & S & S & S & S & S & S & S & S \\
\hline 36 & I - 09101I & $\mathbf{R}$ & $S$ & $S$ & $S$ & $S$ & $S$ & $S$ & $S$ \\
\hline 37 & J - 26061 & S & S & S & S & S & S & S & S \\
\hline 38 & K - 0512 & $\mathbf{R}$ & S & S & S & S & S & S & S \\
\hline 39 & K - 03041 & $S$ & $S$ & $S$ & $S$ & $S$ & $S$ & S & S \\
\hline 40 & K - 15051 & $\mathbf{R}$ & S & S & S & S & $S$ & S & S \\
\hline 41 & K - 19061 & $\mathbf{R}$ & S & S & S & S & S & S & S \\
\hline 42 & K - 07081 & $\mathbf{R}$ & S & S & S & S & $\mathbf{R}$ & S & S \\
\hline 43 & $L-0512$ & S & S & $\mathbf{R}$ & S & S & S & S & S \\
\hline 44 & L - 26061 & $\mathbf{R}$ & S & S & S & S & S & S & S \\
\hline
\end{tabular}

* The letters from A to L correspond to areas of the odontological clinic. R - Resistant, S - Sensible, and I - Intermediary. 


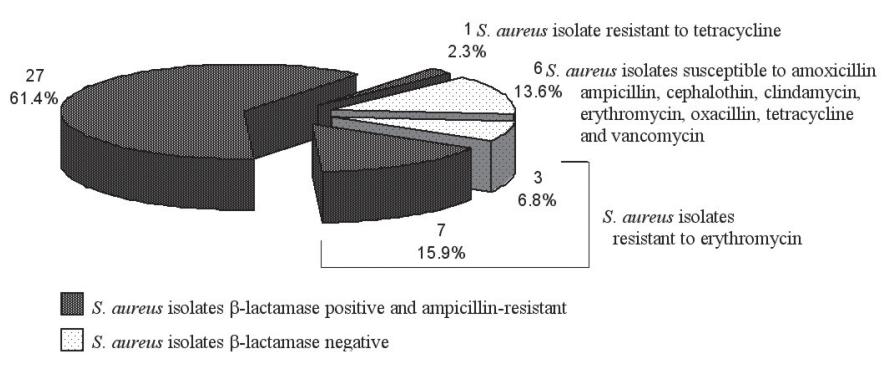

Fig. 3 - $\beta$-lactamase and antibacterial susceptibility assays of $S$. aureus isolates from the odontological clinic environment.

patterns to all the S. aureus isolates (OSSA - Oxacillin-Susceptible Staphylococcus aureus), whose maximum and minimum values were equal to 2 and $0.125 \mu \mathrm{g} . \mathrm{mL}^{-1}$, respectively, on average $0.4 \mu \mathrm{g} \cdot \mathrm{mL}^{-1}$.

\section{DISCUSSION}

Staphylococcus aureus can survive during long periods in the environment and hostile conditions to its development. Consequently, this opportunist pathogen represents a great potential to community and nosocomial infections that can cause superficial (skins) or deep (bacterial endocarditis, septicemia) infections ${ }^{27}$. During 12 months of sample collection (a total of 24 collects) from the odontological clinic environment were isolated 9775 CFU by MSA selective medium. These results suggest a high amount of Staphylococcus spp. in the odontological clinic environment which can appear from aerosols formed during clinical procedures. MATTOS FILHO et al. ${ }^{17}$ showed high prevalence of bacteria (cocci and bacilli) and fungi in the odontological clinic environment. According to LOGOTHETIS et al. ${ }^{16}$, the particles can contain microorganisms capable to cause diseases (tuberculosis, pneumonia, grippe, hepatitis, ocular and skin infections) and to stay dispersed in the air during 30 minutes after the odontological treatment. The aerial spread of microorganisms especially $S$. aureus was demonstrated after buccal prophylaxis ${ }^{1}$ or radiographical $^{31}$ procedures, and during use of pens of high rotation ${ }^{3}$. Such results point out to need of the development of mechanisms capable to minimize the particles spread in the clinical environment, as well as to impede the permanence of contaminant microorganisms, as also suggested by other researchers along the years ${ }^{24,32}$. Some necessary mechanisms to the maximum reduction of the cross-contamination inside odontological environment have been suggested such as (i) preventive measures of protection against the aspersions coming from system of high rotation (use of masks and protecting special glasses), (ii) rigorous anamnesis (when there are suspicions of infect-contagious diseases), (iii) ventilation systems in clinics (air conditioned with renewal device of air that promotes the dispersion of suspended particles), (iv) simple furniture (easy disinfection of precipitate particles).

A total of 3149 colonies $(32.2 \%)$ isolated was suggestive of pathogenic staphylococci by their fermentation of mannitol in selective MSA medium ${ }^{10}$. Used since 1945, the selective Mannitol Salt Phenolred Agar (MSA) medium allows accomplishing a screening or selection of $S$. aureus from samples potentially contaminated ${ }^{11,14}$. Their high concentration of salt $(\mathrm{NaCl} 7.5 \mathrm{~g} \% \mathrm{w} / \mathrm{v})$ tends to inhibit the growth of many microorganisms, however it has great importance to microorganisms of the staphylococci group ${ }^{13}$. In addition, the selectivity of MSA medium has been increased by antimicrobial addition. Some studies used the MSA medium to the selection of oxacillin-resistant $S$. aureus. VAN ENK \& THOMPSON ${ }^{30}$ demonstrated the growth of five (16.7\%) bacterial species and only one (20\%) fungi species by MSA medium added of oxacillin $\left(6 \mathrm{mg} . \mathrm{L}^{-1}\right)$ and polymixin B (10 mg.L $\left.\mathrm{L}^{-1}\right)$. These researchers also demonstrated the growth of 936 specimens isolated from microbiota of the respiratory tract by OMSA (Oxacillin Mannitol Salt Agar) medium. A total of 105 specimens (11.2\%) fermented the mannitol ( $1-0.1 \%$ gram-negative bacillus, $1-0.1 \%$ yeast, and 103 - 11\% staphylococci). Of these, 29 (3.1\%) were identified as $S$. aureus and $74(7.9 \%)$ were identified as coagulase-negative staphylococci. However, other complemental methods have been used to identify $S$. aureus once some microbial species and coagulasenegative staphylococci were capable to accomplish the fermentation by MSA medium. Such methods comprise the coagulase test based on clumping factor (commercial kits), coagulase test (gold standard) and growing in chromogenic medium (CHROMagar Staphylococcus aureus $\left.^{\circledR}\right)^{15,18,19}$. The colonies $(3149-32.2 \%$ ) that fermented by MSA medium and presented gram-positive coloration and catalase-positive characteristics were inoculated on chromogenic medium CHROMagar Staphylococcus aureus ${ }^{\circledR}$. Such chromogenic medium have high specificity and sensibility in detecting of $S$. aureus, whose colonies show mallow color differently of other Staphylococcus spp. colonies that can exhibit white, beige, green or blue color ${ }^{11,19}$. Some researchers have been demonstrating a sensibility of $95-98.5 \%$ from chromogenic medium CHROMagar Staphylococcus aureus ${ }^{\circledR}$ during evaluation of clinical isolates against a sensibility of $82-92 \%$ from conventional methods $^{7,11}$. However, the confirmation of the identity of $S$. aureus becomes indispensable by coagulase test ${ }^{15}$. This test allowed confirming the identity of $44(0.45 \%)$ S. aureus isolates from odontological clinic environment during the isolation.

The enzymes $\beta$-lactamases produced by some bacteria act in the hydrolysis of the ring $\beta$-lactamic of the penicillin which is transformed in acid neutralizing its bactericidal effect. The production test of $\beta$ lactamases commercially available by Cefinase ${ }^{\mathrm{TM}}$ discs (Becton Dickinson \& Company, USA) quickly provide data on resistance of $S$. aureus and other microorganisms ${ }^{8}$ to the antibiotics $\beta$-lactamic (penicillin G, ampicillin, amoxacillin), as well as susceptibility to penicillin $\beta$-lactamase-resistant (methicillin and oxacillin) and cephalosporin (cephalotin). A total of $35 \mathrm{~S}$. aureus isolates $(79.5 \%)$ showed production of $\beta$-lactamase and resistance to ampicillin, erythromycin (seven isolates - 15.9\%) and tetracycline (one isolate $2.3 \%$ ), suggesting the existence of multiresistant isolates. Nine S. aureus isolates $(20.5 \%)$ were $\beta$-lactamase negative and $(i)$ susceptible to all antibacterial (six isolates $-13.7 \%$ ) or (ii) only resistant to erythromycin (three isolates - 6.8\%). ZYGMUNT et al. ${ }^{34}$ showed that $\beta$-lactamases type-A and type-O produced by Staphylococci have high neutralization activities of the nitrocefin, cefazolin and cephapirin, being the type-O less efficient in the hydrolysis of the penicillin G. Recently some researchers have been demonstrating that most of the $S$. aureus isolates (about $90 \%$ of the isolates) coming from several infectious sources (nosocomial infections and other anatomical sites) were resistant to penicillin ${ }^{5,28}$. NA'WAS et al. ${ }^{20}$ demonstrated the existence of infectious nasal $S$. aureus resistant only to penicillin $G$ and ampicillin. In association to our finding, these facts suggest the substitution of the penicillin for alternative antibiotics in cases of odontological infections 
caused by $S$. aureus, however resistotyping assays (antibiogram) should be accomplished in isolates of this bacterial specie coming from several clinical sources in order to administer a specific and efficient treatment to patients. In addition, all the isolates showed antibacterial susceptibility to amoxicillin (only two isolates showed intermediary levels), cephalothin, clindamycin, oxacillin and vancomycin. The evaluation of the minimum inhibitory concentration (MIC) of oxacillin showed susceptibility patterns to all the $S$. aureus isolates (OSSA isolates - Oxacillin-Susceptible Staphylococcus aureus), whose maximum and minimum values were equal to 2 and $0.125 \mu \mathrm{g} \cdot \mathrm{mL}^{-1}$, respectively, on average $0.4 \mu \mathrm{g} \cdot \mathrm{mL}^{-1}$. According to the phenotypic interpretation criterion by Etest ${ }^{\circledR}$ assays such results suggest the inexistence of the mecA gene in chromosomal DNA of $S$. aureus isolated from odontological clinic environment. This gene codifies a protein (PPB2a) that confers resistance to synthetical penicillin (i.e., methicillin and oxacillin) ${ }^{23}$.

Due to medical importance of the pathogen $S$. aureus, the available data in the literature until the moment including our observations point out to the need of a larger knowledge on the contamination means and propagation of this microorganism into the odontological clinic.

\section{RESUMO}

\section{Staphylococcus aureus resistente à ampicilina em ambiente de Clínica Odontológica}

Foi avaliada a prevalência de Staphylococcus spp. e S. aureus no ambiente clínico odontológico, a produção de $\beta$-lactamase e a susceptibilidade antibacteriana aos principais antibióticos utilizados na prática clínica. Durante 12 meses de coleta de amostras foram isolados 9775 UFC no meio de cultura AMS, demonstrando uma elevada quantidade de Staphylococcus spp. no ambiente clínico, provavelmente em decorrência da propagação de aerossóis. Um total de 3149 colônias $(32,2 \%)$ foi sugestivo de estafilococos patogênicos. Coloração de Gram, teste de catalase, crescimento de colônias-malva sobre meio cromogênico e teste de coagulase confirmaram a identidade de $44(0,45 \%)$ isolados de S. aureus. Destes, 35 isolados $(79,5 \%)$ mostraram produção de $\beta$-lactamase através de discos de Cefinase ${ }^{\mathrm{TM}} \mathrm{e}$ resistência a ampicilina, eritromicina ( 7 isolados) e tetraciclina (1 isolado), sugerindo a existência de isolados multirresistentes. A avaliação do MIC de oxacilina através dos ensaios de Etest ${ }^{\circledR}$ mostrou padrões de susceptibilidade o que sugere a inexistência do gene mecA gene no DNA cromossômico. Estes resultados apontam para a necessidade de um maior conhecimento sobre os meios de contaminação e propagação deste microrganismo dentro da clínica odontológica.

\section{ACKNOWLEDGMENTS}

This research work was supported by FAPESP - Fundação de Amparo à Pesquisa do Estado de São Paulo (Proc. 00/09183-0).

\section{REFERENCES}

1. AUTIO, K.L.; ROSEN, S.; REYNOLDS, N.J. \& BRIGHT, J.S. - Studies on crosscontamination in the dental clinic. J. Amer. dent. Ass., 100: 358-361, 1980.
2. BAUER, A.W.; KIRBY, W.M.; SHERRIS, J.C. \& TURCK, M. - Antibiotic susceptibility testing by standardized single disk method. Amer. J. clin. Path., 45: 493-496, 1966.

3. BENTLEY, C.D.; BURKHART, N.W. \& CRAWFORD, J.J. - Evaluating spatter and aerosol contamination during dental procedures. J. Amer. dent. Ass., 125: 579-584, 1994.

4. BERNARDS, A.T.; FRENAY, H.M.; LIM, B.T. et al. - Methicillin-resistant Staphylococcus aureus and Acinetobacter baumannii: an unexpected difference in epidemiologic behavior. Amer. J. Infect. Control, 26: 544-551, 1998.

5. BOOTH, M.C.; PENCE, L.M.; MAHASRESHTI, P.; CALLEGAN, M.C. \& GILMORE, M.S. - Clonal associations among Staphylococcus aureus isolates from various sites of infection. Infect. Immun., 69: 345-352, 2001.

6. BROWN, D.F.J.; BRENWALD, N.P. \& CONSTANTINE, C.E. - Detection of Oxacillin/ Methicillin resistance in Staphylococcus aureus with Etest MIC method. Chicago, ICAAAC, 1991.

7. CARRICAJO, A.; TRENY, A.; FONSALE, N. et al. - Performance of the chromogenic medium CHROMagar Staphy aureus and the Staphychrom coagulase test in detection and identification of Staphylococcus aureus in clinical specimens. J. clin. Microbiol., 39: 2581-2583, 2001

8. COCKERILL $3^{\text {rd }}$, F.R. - Genetic methods for assessing antimicrobial resistance. Antimicrob. Agents Chemother., 43: 199-212, 1999.

9. DIAS, C.A.; KADER, I.A.; D'AZEVEDO, P. et al. - Comparison of the E test with agar dilution for determining susceptibility of Streptococcus pneumoniae to penicillin. Rev. Microbiol. (S. Paulo), 29: 130-133, 1998.

10. FINEGOLD, M.S. \& BARON, E.J. - Diagnóstico microbiológico. 7. ed. Buenos Aires, Medica Panamericana, 1989.

11. GAillot, O.; WETSCH, M.; FORTINEAU, N. \& BERCHE, P. - Evaluation of CHROMagar Staph. aureus, a new chromogenic medium, for isolation and presumptive identification of Staphylococcus aureus from human clinical specimens. J. clin. Microbiol., 38: 1587-1591, 2000.

12. HORIBA, N.; YOSHIDA, T.; SUZUKI, K. et al. - Isolation of methicillin-resistant staphylococci in dental operatory. J. Endod., 21: 21-25, 1995.

13. KAMPF, G.; LECKE, C.; CIMBAL, A.; WEIST, K. \& RÜDEN, H. - Evaluation of mannitol salt agar for detection of oxacillin resistance in Staphylococcus aureus by disk diffusion and agar screening. J. clin. Microbiol., 36: 2254-2257, 1998.

14. KLUYTMANS, J.; VAN LEEUWEN, W.; GOESSENS, W. et al. - Food-initiated outbreak of methicillin-resistant Staphylococcus aureus analyzed by pheno- and genotyping. J. clin. Microbiol., 33: 1121-1128, 1995.

15. KONEMAN, E.W.; ALLEN, S.D.; JANDA, W.M.; SCHRECKENBERGER, P.C. \& WINN Jr, W.C. - Introduction to diagnostic Microbiology. Philadelphia, J.B. Lippincott, 1994. p. $187-198$.

16. LOGOTHETIS, D.D.; GROSS, K.B.W.; EBERHART, A. \& DRISKO, C. - Bacterial airborne contamination with an air polishing device. Gen. Dent., 36:.496-499, 1988.

17. MATTOS-FILHO, T.R.; PACHECO, A.B.N.D. \& GROPPO, F.C. - Identification and increase pattern of prevalent microorganisms in clinical environment. In: International Association for Dental Research Divisional meetings, 1998-1999. Abstracts. J. dent. Res., 78: 1006, 1999.

18. MAZA, L.M.; PEZZOLO, M.T. \& BARON, E.J. - Atlas de diagnóstico em Microbiologia. Porto Alegre, Artes Médicas Sul, 1999.

19. MERLINO, J.; LEROI, M.; BRADBURY, R.; VEAL, D. \& HARBOUR, C. - New chromogenic identification and detection of Staphylococcus aureus and methicillinresistant S. aureus. J. clin. Microbiol., 38: 2378-2380, 2000. 
20. NA'WAS, T.; HAWWARI, A.; HENDRIX, E. et al. - Phenotypic and genotypic characterization of nosocomial Staphylococcus aureus isolates from trauma patients. J. clin. Microbiol., 36: 414-420, 1998.

21. NATIONAL COMMITTEE FOR CLINICAL LABORATORY STANDARDS Performance Standards for Antimicrobial Disk Susceptibility Tests. National Committee For Clinical Laboratory Standards. Villanova, 1994. (Approved Standard. M2-15, 14(16), 1994).

22. NEIDLE, E.A. \& YAGIELA, J.A. - Farmacologia e terapêutica para dentistas. 3. ed. Rio de Janeiro, Guanabara-Koogan, 1991.

23. OLIVEIRA, A.M. \& RAMOS, M.C. - PCR ribotyping of Staphylococcus aureus. Braz. J. med. biol. Res., 35: 175-180, 2002.

24. RANALI, J.; MATTOS FILHO, T.R. \& GONÇALVES, R.B. - Eficiência de máscaras cirúrgicas frente a aspersões produzidas por alta rotação. Rev. bras. Odont. (S. Paulo), 49: 46-48, 1992.

25. SNEATH, P.H.; MAIR, N.S.; SHARPE, M.N. \& HOLT, J.G. - Bergey's manual of systematic Bacteriology. Baltimore, Williams \& Wilkins, 1986. v. 2.

26. SUZUKI, J.; KOMATSUZAWA, H.; KOZAI, K. \& NAGASAKA, N. - In vitro susceptibility of Staphylococcus aureus including MRSA to four disinfectants. ASDC J. Dent. child., 64: 260-263, 1997.

27. TENOVER, F.C.; ARBEIT, R.; ARCHER, G. et al. - Comparison of traditional and molecular methods of typing isolates of Staphylococcus aureus. J. clin. Microbiol., 32: $407-415,1994$.
28. THORNSBERRY, C. - Trends in antimicrobial resistance among today's bacterial pathogens. Pharmacotherapy, 15(1 pt. 2): 3S-8S, 1995.

29. VALENCIA, E.M.; ENRIQUEZ, A.; SORIANO, V. et al. - Nosocomial infection with methicillin resistant Staphylococcus aureus in 14 human immunodeficiency virus infected patients. Med. clin. (Barcelona), 109: 261-263, 1997.

30. VAN ENK, R.A. \& THOMPSON, K.D. - Use of a primary isolation medium for recovery of methicillin-resistant Staphylococcus aureus. J. clin. Microbiol., 30: 504-505, 1992.

31. WHITE, S.C. \& GLASE, S. - Interpatient microbiological cross-contamination after dental radiographic examination. J. Amer. dent. Ass., 96: 801-804, 1978.

32. WOOD, P. - Controversies in cross-infection-control. Brit. dent. J., 10: 249-251, 1993.

33. ZANON, U. \& NEIG, J - Infecções hospitalares: prevenção, diagnóstico e tratamento. Rio de Janeiro, Editora Médica Científica, 1987.

34. ZYGMUNT, D.J.; STRATTON, C.W. \& KERNODLE, D.S. - Characterization of four beta-lactamases produced by Staphylococcus aureus. Antimicrob. Agents Chemother., 36: 440-445, 1992.

Received: 23 April 2004

Accepted: 11 November 2004 